УДК 658.8.012.12

DOI: https://doi.org/10.26642/jen-2020-4(94)-29-44

К.В. Шиманська, д.е.н., доц. Т.О. Завалій, аспірантка

Державний університет «Житомирська політехніка»

\title{
Аналіз розвитку перспективи «Кліснти» збалансованої системи показників у працях вчених
}

\begin{abstract}
Аналіз тематики дослідження перспективи збалансованої системи показників, щуо відповідає за відносини з клієнтами, структурований за такими питаннями, як назва цієї перспективи, ї̈ стратегічні иілі, показники, стратегічні ініціативи, відповідне інформаційне забезпечення управління та інтеграція такої концепції з іншими підходами в управлінні. Рекомендовано 3 метою управління системою відносин з клієнтами в межах реалізації збалансованої системи показників для відповідної перспективи використовувати назву «Клієнти».

Стратегічні иілі перспективи «Клієнти» конкретизуються з огляду на специфіку стратегіі підприємства та бачення власної місії в середовищі, в якому воно функціонує, але класичний підхід передбачає такі стратегічні, иілі як збільшення частки ринку, збереження клієнтської бази, розширення клієнтської бази, задоволення потреб клієнта, збільшення прибутковості клієнта. Запропоновано в межах перспективи «Клієнти» використовувати групування показників за ознаками, щзо характеризують: позицію підприємства на ринку; клієнтську базу підприємства; рівень задоволеності клієнтів підприємства; особливості пропозиції підприємства; надходження / видатки, пов'язані з клієнтами, та ефективність використання клієнтського капіталу підприємства.

На відміну від стратегічних цілей обрані ініціативи повинні мати конкретний характер сукупності дій для реалізації изілі, до якої вони підпорядковані. Інформаційне забезпечення використання збалансованої системи показників здебільшого представлено картками показників та стратегічними картами, що можуть будуватися на різних рівнях підпорядкування. Обтрунтовано, щзо можливості інтеграції концепції ЗСП з іншими підходами в управлінні забезпечують їй високий рівень адаптивності в управлінській практиці.
\end{abstract}

Ключові слова: збалансована система показників; ЗСП; клієнти; перспектива «Клієнти»; відносини з клієнтами; показники; стратегія; стратегічна карта; стратегічні иілі; стратегічні ініціативи.

Актуальність теми. Актуальність концепції збалансованої системи показників (далі - ЗСП) як інструменту організації ефективного процесу управління 3 метою реалізації обраної стратегії підтверджується значною увагою до неї в дослідженнях українських науковців. Бачення ЗСП як методу схематичної структуризації найрізноманітніших питань уможливлює дослідження тих сфер, які оцінити тільки за допомогою фінансових показників майже неможливо, а встановлення відповідних причиннонаслідкових зв'язків дозволяе зрозуміти вплив результатів функціонування однієї сфери діяльності на іншу. Квінтесенція дослідження ЗСП полягає в тому, що ця методика настільки універсальна та адаптивна, що може використовуватися в інтеграції з багатьма іншими підходами в управлінні та стосовно різних об’єктів управління, чи то певна діяльність підприємства, чи то сфера відповідальності окремого підрозділу. Тому вивчення особливостей побудови ЗСП, зокрема її структури, є актуальним 3 точки зору глибшого розуміння цього явища в управлінні. Об'єкт уваги статті - перспектива «Клієнти», що беззаперечно $\epsilon$ атрибутом успіху в ефективному управлінні підприємством на базі ЗСП в умовах впливу зовнішнього середовища, наявності конкуренції та необхідності підтримки грошових надходжень, джерелами яких для підприємства є клієнти.

Одним із обмежень цього дослідження є те, що аналіз пропозицій авторів щодо перспективи «Клієнти» проводиться без прив'язки до інших перспектив ЗСП, тобто без врахування причинно-наслідкових зв'язків між ними. Такий момент обмежує можливості бачення процесів реалізації ЗСП на підприємстві в цілому, але уможливлює розгляд перспективи «Клієнти» окремо від інших перспектив ЗСП.

Аналіз останніх досліджень і публікацій. Коло питань, пов'язаних з особливостями застосування концепції ЗСП як окремо, так і в інтеграції з іншими управлінськими підходами, як відносно всієї діяльності підприємства в цілому, так і в аспекті ї різних видів досліджували такі автори, як О.В. Ачкасова, Н.М. Головай, Т.М. Мельник, О.В. Мінєнкова, І.В. Науменко, Г.Й. Островська, Р.О. Побережний, С.В. Поліщук, І.В. Пономарьова, Х.Я. Соловій, О.О. Трут, С.О. Фаізова, А.В. Шайкан, А.В. Штереверя, І.М. Ягнюк, І.Й. Яремко, І.В. Ярошенко та інші.

(C) К.В. Шиманська, Т.О. Завалій, 2020 
Метою статті є аналіз, систематизація і узагальнення підходів та пропозицій з дисертаційних досліджень, захищених в Україні, стосовно перспективи «Клієнти» як однієї з можливих структурних елементів управління, побудованого на основі ЗСП.

Викладення основного матеріалу. Наявність перспективи «Клієнти» в межах реалізації ЗСП не $\epsilon$ обов'язковою умовою, адже побудова стратегічної карти та поділ їі на перспективи є компетенцією менеджерів, які можуть індивідуально обирати стратегічно важливі аспекти діяльності для конкретного підприємства. Але 3 огляду на те, що саме клієнти є джерелом грошових надходжень і запорукою стабільного функціонування суб'єкта господарювання, врахування сфери відносин 3 клієнтами в управлінській діяльності є неодмінно важливою складовою вивчення процесу запровадження ЗСП на підприємстві.

ЗСП є інструментом побудови механізму процесів управління в різних дисертаційних дослідженнях. Зокрема, українськими дослідниками ЗСП використовується та видозмінюється для вирішення питань та проблем різних економічних спеціальностей. Увага цієї роботи поширюється на ті дослідження, які безпосередньо вивчають аспекти використання ЗСП на рівні окремого підприємства, а це такі спеціальності, як 08.00.04 «Економіка та управління підприємствами» (26 праць), 08.00 .09 «Бухгалтерський облік, аналіз та аудит» (4 праці), 08.00.11 «Математичні методи, моделі та інформаційні технології в економіці» (2 праці). Коло обраних праць налічило 32 дисертаційних дослідження, але тематика ЗСП висвітлена в набагато більшій кількості робіт подібного характеру.

Аналіз обраної тематики структурований за такими питаннями:

- назва перспективи ЗСП, що відповідає за відносини з клієнтами;

- стратегічні цілі перспективи «Клієнти»;

- показники перспективи «Клієнти»;

- стратегічні ініціативи (заходи) перспективи «Клієнти»;

- інформаційне забезпечення управління в межах використання ЗСП;

- інтеграція ЗСП з іншими підходами в управлінні.

1.1. Назва перспективи ЗСП, щчо відповідає за відносини з клієнтами. Аналіз підходів дослідників щодо назви перспективи ЗСП (табл. 1), що відповідає за відносини 3 клієнтами та їх ефективність для підприємства, засвідчив відсутність одностайності думок. Однак відсутні і суттєві розбіжності.

Таблиия 1

Варіації назв перспективи ЗСП, щзо відповідає за відносини з клієнтами, в дисертаційних дослідженнях, захищених в Украйні

\begin{tabular}{|c|c|c|l|}
\hline $\begin{array}{c}\text { № } \\
3 / n\end{array}$ & Piк & \multicolumn{1}{|c|}{ Автор } & \multicolumn{1}{c|}{ Назва перспективи* } \\
\hline 1 & 2007 & М.В. Височина [3, с. 107] & $\begin{array}{l}\text { Ефективність управління } \\
\text { діяльністю }\end{array}$ \\
\hline 2 & 2007 & Н.О. Іванченко [8, с. 138] & Складова «Клієнти» \\
\hline 3 & 2007 & Г.Й. Островська [19, с. 169, 172] & Перспектива «Клієнти», споживацький напрям \\
\hline 4 & 2007 & І.В. Шварц [29, с. 82, 85, 144] & Маркетингова діяльність, маркетинговий аспект \\
\hline 5 & 2008 & І.В. Ярошенко [33, с. 181] & Перспектива «Клієнти» \\
\hline 6 & 2009 & Н.М. Головай [5, с. 161] & Аспект «Відносини з покупцями та комунікації» \\
\hline 7 & 2009 & М.В. Кадничанський [9, с. 98-99] & $\begin{array}{l}\text { Клієнтська складова, компонента } \\
\text { «Клієнти / ринок», складова «Клієнти» }\end{array}$ \\
\hline 8 & 2009 & Р.П. Підлипна [20, с. 57-58] & Перспектива «Ринок / клієнти» \\
\hline 9 & 2009 & М.С. Сапачова [24, с. 92] & Напрям «Клієнти» \\
\hline 10 & 2009 & А.В. Шайкан [28, с. 64, 194, 384] & $\begin{array}{l}\text { Споживча перспектива, напрям «Стосунки } \\
\text { клієнтами» }\end{array}$ \\
\hline 11 & 2010 & О.О. Курносова [12, с. 85, 130] & Аспект «Клієнти» \\
\hline 12 & 2010 & А.В. Штереверя [30, с. 71] & Маркетингова складова \\
\hline 13 & 2010 & І.М. Ягнюк [31, с. 49, 82] & Проєкція «Клієнти» \\
\hline 14 & 2010 & І.Й. Яремко [32, с. 225] & Перспектива «Клієнти» \\
\hline 15 & 2011 & О.В. Ачкасова [2, с. 3, 6, 8] & Клієнтська складова \\
\hline 16 & 2011 & І.В. Пономарьова [23, с. 30, 69] & Клієнтська складова \\
\hline 17 & 2013 & Х.Я. Соловій [25, с. 3] & Співробітництво з контрагентами \\
\hline 18 & 2014 & С.В. Поліщук [22, с. 118, 138] & Напрямок «Клієнти», група «Клієнти» \\
\hline 19 & 2015 & Н.М. Андрієнко [1, с. 144, 208] & Перспектива споживачів, напрямок «Споживачі» \\
\hline 20 & 2015 & Т.М. Мельник [16, с. 253] & Стратегічна перспектива «Клієнти» \\
\hline 21 & 2015 & І.В. Науменко [18, с. 48, 60, 185] & Компонента «Зовнішні процеси» \\
\hline & & &
\end{tabular}


Закінчення табл. 1

\begin{tabular}{|c|c|c|l|}
\hline 22 & 2015 & Р.О. Побережний [21, с. 179, 236, 48] & Клієнтська складова чи складова «Клієнти» \\
\hline 23 & 2015 & С.О. Фаізова [27, с. 84] & Перспектива «Клієнти» \\
\hline 24 & 2016 & М.М. Іваннікова [7, с. 168, 211] & $\begin{array}{l}\text { Напрям діяльності «Зовнішнє оточення», } \\
\text { споживча складова }\end{array}$ \\
\hline 25 & 2017 & В.І. Вострякова [4, с. 155, 157] & Аспект чи елемент «Споживач» \\
\hline 26 & 2018 & В.І. Лемішковський [13, с. 5, 104] & Група «Клієнти» \\
\hline 27 & 2018 & Ю.О. Лецер [14, с. 57] & Група «Клієнти» \\
\hline 28 & 2018 & О.В. Мінєнкова [17, с. 96, 100] & Клієнтська складова \\
\hline 29 & 2019 & О.А. Жигулін [6, с. 162, 185] & Клієнтська складова, маркетингова компонента \\
\hline 30 & 2019 & Б.Б. Каргін [11, с. 97] & Перспектива «Цифровий маркетинг» \\
\hline 31 & 2019 & Г.В. Малахівська [15, с. 226] & Перспектива «Клієнти та ринок» \\
\hline 32 & 2019 & О.О. Трут [26, с. 93, 307, 315, 339] & $\begin{array}{l}\text { Клієнтський аспект, перспектива з боку клієнта, } \\
\text { перспектива «Клієнти», клієнтська складова }\end{array}$ \\
\hline \multicolumn{3}{|l}{ Примітка: $*$-перспектива може аналогічно називатися авторами складовою, напрямом, компонентою, аспектом, проєкцією тощо }
\end{tabular}

Проведений аналіз дозволив узагальнити підходи до назви такої перспективи та сформувати вказані висновки. Дослідники здебільшого віддають перевагу назві «перспектива «Клієнти»» чи аналогічній назві з використанням терміна «клієнти». Вважаємо такі назви, як «перспектива / напрям / складова / група / проєкція / аспект «Клієнти»"», «стратегічна перспектива «Клієнти»», «клієнтська складова», «клієнтський аспект», «напрям «Стосунки з клієнтами»» взаємозамінними, адже їх сутнісне наповнення $є$ майже однаковим. Якщо дослідження проводиться з боку підприємства, то назва «Перспектива $з$ боку клієнта», яка зустрічається в дисертації О.О. Трут, є не зовсім коректною, адже підприємство, а не клієнт / клієнти, управляє ефективністю взаємними відносинами.

Схожим, але дещо більш розгалуженим є підхід, що передбачає назву подібної перспективи як «Клієнти / ринок» (М.В. Кадничанський), «Клієнти та ринок» (Г.В. Малахівська), «Ринок / клієнти» (Р.П. Підлипна). Тут авторський підхід полягає в сприйнятті клієнтів саме в середовищі, тобто на ринку. Деякі автори зосереджені власне не на клієнтах, а на специфіці зовнішнього середовища та на зовнішніх учасниках, які взаємодіють 3 підприємством. Наприклад, Х.Я. Соловій [25, с. 10, 18] пропонує напрям «клієнти» («маркетинг») замінити на «співробітництво 3 контрагентами», доповнивши його чинниками мікросередовища (конкуренти, покупці, постачальники, зовнішні партнери) та макросередовища (екологія, рівень НТП та політико-правові відносини). Авторка підкреслює, що стандартні складові ЗСП не враховують усі напрями і фактори впливу на інноваційну діяльність вітчизняних підприємств, тому таке включення до їі складу чинників зовнішнього оточення дозволить менеджерам виявити коло зацікавлених осіб, оцінити і контролювати рівень їх впливу на інноваційний розвиток підприємства.

Аналогічно синонімами будуть такі назви досліджуваної перспективи, в яких фігурує термін «маркетинг», зокрема «ефективність управління маркетинговою діяльністю», «маркетингова діяльність», «маркетингова компонента», «маркетингова складова», «маркетинговий аспект». На наш погляд, подібна назва цієї перспективи обмежує її в рамках діяльності відділу чи служби маркетингу (з прив'язкою саме до цієї діяльності в межах функціонування підприємства), тому вважаємо такий підхід дещо звуженим. Зустрічається перспектива «Цифровий маркетинг», назва якої завдячує тому, що автор (Б.Б. Каргін) розробив стратегічну карту з урахуванням цифрової трансформації бізнесу як основного інструменту стратегічного планування. На його думку, перспектива «Цифровий маркетинг» визначає пропозицію організаційної цінності і підвищує лояльність клієнтів до бренда компанії. Істотною пропозицією як для бізнесу, так і для клієнта, буде створення цифрової екосистеми, за якої нематеріальні активи створять вартість і збільшать цінність продукту за допомогою застосування програмних інструментів і систем управління [11, с. 96-97]. Це ще раз доводить, що індивідуальні особливості підходу дослідження можуть змінювати назви перспектив ЗСП з огляду на ті управлінські питання, які будуть вирішуватися за іiі допомогою.

Зважаючи на те, що концепція ЗСП (Balanced scorecard, BSC) започатковувалася в англомовному середовищі, та що у в Р.С. Каплана та Д.П. Нортона використовувалося слово «Сustomer», вважаємо найкоректнішим для вживання термін «Клієнти» для позначення відповідних відносин. Терміни «Споживачі» та «Покупці» обмежують розуміння кола учасників, на яких зорієнтована управлінська діяльність підприємства в межах досліджуваної перспективи ЗСП. Назва перспективи «Споживачі» буде адекватною у випадку дослідження підприємством споживчої вартості чи корисності власної продукції (послуг, робіт) для своїх споживачів - тих, хто споживає ці товари. Аналогічно назва «Покупці» буде коректною для вивчення саме відносин з тими, хто купує продукцію підприємства.

Деякі автори синонімічно використовують назви перспективи клієнти/споживачі (Г.Й. Островська, A.В. Шайкан), клієнти / маркетинг (О.А. Жигулін), зовнішнє оточення/споживча складова (М.М. Іваннікова), що $з$ нашого боку не підтримується через те, що, по-перше, наповнення термінів 
«клієнти», «споживачі», «маркетинг» мають свої особливості, що під час практичної реалізації має відображатися на наповненні елементів цієї перспективи (стратегічні цілі, показники, стратегічні ініціативи), по-друге, дослідження клієнтів апріорі передбачає врахування особливостей ринку чи зовнішнього середовища.

1.2. Стратегічні цุiлi перспективи «Клієнти». Такий елемент ЗСП як стратегічні цілі має вирішальне значення, адже саме вони формують чіткі орієнтири для управлінців в процесі реалізації стратегії в цілому. В межах перспективи «Клієнти» стратегічні цілі мають визначати політику підприємства відносно клієнтів задля дотримання стратегічно орієнтованого вектора. Класичний підхід (Р.С. Каплан, Д.П. Нортон [10, с. 55]) передбачає такі основні стратегічні цілі в перспективі «Клієнти», як збільшення частки ринку, збереження клієнтської бази, розширення клієнтської бази, задоволення потреб клієнта, збільшення прибутковості клієнта. Запропоновані дослідниками стратегічні цілі ЗСП знаходять підтримку і з боку українських дослідників, про що свідчать дані таблиці 2.

Таблиця 2

Основні стратегічні ціллі в перспективі «Клієнти»

\begin{tabular}{|c|c|c|}
\hline $\begin{array}{l}\text { № } \\
3 / n\end{array}$ & Основні стратегічні ијілі & Дослідники, які виокремлюють стратегічні иүілі \\
\hline 1 & $\begin{array}{c}\text { Збільшення частки ринку } \\
\text { (в т. ч. доступ до нових ринків) }\end{array}$ & $\begin{array}{l}\text { О.В. Ачкасова [2, с. 10], М.В. Кадничанський [9, с. 98-99], } \\
\text { Б.Б. Каргін [11, с. 229], О.В. Мінєнкова [17, с. 206], } \\
\text { Г.Й. Островська [19, с. 172], С.В. Поліщук [22, с. 96], } \\
\text { І.В. Пономарьова [23, с. 30], С.О. Фаізова [27, с. 84], } \\
\text { А.В. Шайкан [28, с. } 384] \text {, І.В. Шварц [29, с. } 85], \\
\text { А.В. Штереверя [30, с. 30], І.М. Ягнюк [31, с. 82] }\end{array}$ \\
\hline 2 & $\begin{array}{l}\text { Збереження клієнтської бази } \\
\text { (в т. ч. їі створення, збереження } \\
\text { певних груп клієнтів) }\end{array}$ & $\begin{array}{l}\text { О.В. Ачкасова [2, с. 10], Н.М. Головай [5, с. 165], } \\
\text { Б.Б. Каргін [11, с. 229], О.В. Мінснкова [17, с. 206], } \\
\text { Г.Й. Островська [19, с. 172], І.В. Пономарьова [23, с. 30, 69], } \\
\text { А.В. Шайкан [28, с. 384], А.В. Штереверя [30, с. 30], } \\
\text { I.М. Ягнюк [31, с. 82] }\end{array}$ \\
\hline 3 & Розширення клієнтської бази & $\begin{array}{l}\text { О.В. Ачкасова [2, с. 10], Б.Б. Каргін [11, с. 229], } \\
\text { Г.В. Малахівська [15, с. 226], І.В. Пономарьова [23, с. 30, 69], } \\
\text { Х.Я. Соловій [25, с. 12], А.В. Шайкан [28, с. 384], } \\
\text { А.В. Штереверя [30, с. 30], І.М. Ягнюк [31, с. 82] }\end{array}$ \\
\hline 4 & $\begin{array}{c}\text { Задоволення потреб клієнта } \\
\text { (в т. ч. шляхом забезпечення } \\
\text { своєчасності доставки, } \\
\text { підвищення якості продукції } \\
\text { (послуг, робіт), реклами, збутової } \\
\text { політики, розширення } \\
\text { асортименту, наявності діючого } \\
\text { вебсайту, впровадження } \\
\text { інформаційних технологій тощо) }\end{array}$ & $\begin{array}{l}\text { Н.М. Андрієнко [1, с. 144], В.І. Вострякова [4, с. 158], } \\
\text { Н.М. Головай [5, с. 165], О.А. Жигулін [6, с. 162], } \\
\text { Н.О. Іванченко [8, с. 138], Б.Б. Каргін [11, с. 229], } \\
\text { О.В. Мінєнкова [17, с. 206], І.В. Науменко [18, с. 56, 184], } \\
\text { Г.Й. Островська [19, с. 168-169, 173], С.В. Поліщук [22, с. 96], } \\
\text { І.В. Пономарьова [23, с. 30, 69], Х.Я. Соловій [25, с. 12], } \\
\text { С.О. Фаізова [27, с. 84], А.В. Шайкан [28, с. 384], } \\
\text { І.В. Шварц [29, с. 85, 144], А.В. Штереверя [30, с. 30], } \\
\text { І.В. Ярошенко [33, с. 181-182], І.М. Ягнюк [31, с. 82] }\end{array}$ \\
\hline 5 & $\begin{array}{c}\text { Збільшення } \\
\text { прибутковості клієнта }\end{array}$ & $\begin{array}{l}\text { А.В. Шайкан [28, с. 384], А.В. Штереверя [30, с. 30], } \\
\text { I.М. Ягнюк [31, с. 82] }\end{array}$ \\
\hline
\end{tabular}

Цей перелік (табл. 2) не є вичерпним і кожна із зазначених вище стратегічних цілей може бути ще більше конкретизована 3 огляду на специфіку стратегії підприємства та бачення власної місії в середовищі, в якому воно функціонує. Окрім вказаних вище п'яти основних стратегічних цілей, автори виокремлюють й інші, зважаючи на особливості дослідження. Наприклад, забезпечення екологічності продукції (В.І. Вострякова), використання торгової марки (корпоративний брендінг) (М.В. Кадничанський), зростання лояльності до бренда (Г.В. Малахівська), формування конкурентних цін (І.В. Науменко), досягнення лідируючих позицій на ринку за рахунок інновацій (С.О. Фаізова), підвищення сили бренда (С.О. Фаізова), лояльність клієнтів (І.Й. Яремко), досягнення лідерства в галузі за обсягом продажів в розрахунку на одного робітника (І.В.Ярошенко), лідерство на ринку за інноваційною продукцією (І.В. Ярошенко) тощо.

Найбільша увага дослідників зосереджується на такій стратегічній цілі, як задоволення потреб клієнта, що зумовлено тим, що в коло уваги такого напряму розвитку входить широкий спектр підцілей, що мають досягатися з метою втримання підприємством своїх конкурентних позицій.

Підхід до кількості обраних стратегічних цілей в межах перспективи «Клієнти» $\epsilon$ суто індивідуальним з позиції кожного окремого випадку. Але наведені в таблиці 2 стратегічні цілі є базовими 
для керівництва та для вибору власного варіанта переліку необхідних напрямів реалізації загальної стратегії, дотримуючись принципу причинно-наслідкових зв’язків між перспективами.

Автори досліджують питання стратегічних цілей (напрямів реалізації стратегії) як в загальному вигляді, так і з прив'язкою до конкретного підприємства чи підприємств конкретної галузі.

1.3. Показники перспективи «Клієнти». Пропозиції дослідників щодо аналітичного забезпечення процесів управління відносинами з клієнтами в межах перспективи «Клієнти» (чи іншої обраної назви) можна об'єднати в три основні підходи:

1) окремі показники;

2) показники відповідно до визначених стратегічних цілей;

3) показники, які розраховуються на основі попередньо розрахованих показників, тобто вони $є$ інтегральними і комплексно мають характеризувати об'єкт. Цей підхід можна умовно поділити на дві групи;

- перша група пропонує один інтегральний показник, що комплексно характеризує перспективу «Клієнти» (наприклад, Р.О. Побережний - інтегральний показник розвитку клієнтської складової ЗСП [21, с. 190]; С.В. Поліщук - індекс-згортка показників групи «Клієнти» [22, с. 138]);

- друга група пропонує показник/ показники, що характеризує певні особливості перспективи «Клієнти» i може використовуватися для управління відносинами 3 клієнтами (наприклад, Г.Й. Островська - індекс задоволеності клієнта та індекс споживацької вартості, що розраховуються на основі агрегації фінансових та нефінансових показників [19, с. 173]; М.М. Іваннікова - рівень прихильності споживачів [7, с. 199]).

Аналіз досліджуваних дисертаційних робіт щодо запропонованих до використання показників для перспективи «Клієнти» в межах реалізації ЗСП дозволив систематизувати їх у групи.

Перша група - показники, що характеризують позицію підприємства на ринку (табл. 3).

Табличя 3

Показники перспективи «Клієнти», щуо характеризують позицію підприємства на ринку

\begin{tabular}{|c|c|c|}
\hline $\begin{array}{l}\text { № } \\
3 / n\end{array}$ & Показник & Автори, які пропонують показник до використання \\
\hline 1 & Частка ринку & $\begin{array}{l}\text { О.В. Ачкасова, М.В. Височина, Н.М. Головай, } \\
\text { О.А. Жигулін, М.М. Іваннікова, О.О. Курносова, } \\
\text { І.В. Науменко, Г.Й. Островська, С.В. Поліщук, } \\
\text { І.В. Пономарьова, А.В. Шайкан, І.В. Шварц, } \\
\text { А.В. Штереверя, І.М. Ягнюк }\end{array}$ \\
\hline 2 & Частка регіонального ринку & М.В. Кадничанський \\
\hline 3 & Частка національного ринку & М.В. Кадничанський \\
\hline 4 & Частка внутрішнього ринку & О.О. Курносова \\
\hline 5 & $\begin{array}{c}\text { Частка ринку за стратегічними зонами } \\
\text { господарювання }\end{array}$ & С.О. Фаізова \\
\hline 6 & Частка ринку за товарною групою & Б.Б. Каргін \\
\hline 7 & $\begin{array}{c}\text { Відповідність реальної частки ринку } \\
\text { плановій }\end{array}$ & О.А. Жигулін \\
\hline 8 & $\begin{array}{c}\text { Темпи зростання обсягів експорту, } \\
\text { в т. ч. у стратегічних сегментах } \\
\text { та за географією ринку }\end{array}$ & С.О. Фаізова \\
\hline 9 & $\begin{array}{c}\text { Бізнес-досвід } \\
\text { (період функціонування підприємства) }\end{array}$ & М.В. Кадничанський \\
\hline 10 & Конкурентоспроможність підприємства & М.М. Іваннікова \\
\hline 11 & Кількість конкурентів & І.В. Науменко, А.В. Штереверя \\
\hline
\end{tabular}

Центральним показником в групі, наведеній в таблиці 3, є частка ринку, що демонструє місце конкретного підприємства відносно інших учасників, зокрема конкурентів, на ринку. Показники цієї групи можуть конкретизувати частку ринку як різних регіональних рівнів (населений пункт, місто, область, ціла країна, інші країни), так і в розрізі продукції (окремих товарів, послуг, робіт). Саме ця група показників зосереджена на тому, щоб характеризувати підприємство як учасника ринку, враховуючи вплив зовнішнього середовища.

Друга група - показники, що характеризують клієнтську базу підприємства (табл. 4). 
Показники перспективи «Клієнти», щуо характеризують клієнтську базу підприємства

\begin{tabular}{|c|c|c|}
\hline $\begin{array}{l}\text { Noo } \\
3 / n\end{array}$ & Показник & $\begin{array}{c}\text { Aвтори, які пропонують показник } \\
\text { до використання }\end{array}$ \\
\hline 1 & Темпи приросту клієнтської бази & О.В. Ачкасова \\
\hline 2 & Коефіцієнт розширення клієнтської бази & I.В. Пономарьова \\
\hline 3 & Кількість клієнтів & І.В. Пономарьова, А.В. Штереверя \\
\hline 4 & Кількість чи частка постійних клієнтів & $\begin{array}{l}\text { В.І. Лемішковський, Г.В. Малахівська, } \\
\text { І.В. Науменко }\end{array}$ \\
\hline 5 & Діючі клієнти за товарною групою & Б.Б. Каргін \\
\hline 6 & Кількість чи частка нових клієнтів & $\begin{array}{l}\text { Н.М. Андрієнко, М.В. Височина, } \\
\text { М.М. Іваннікова, О.О. Курносова }\end{array}$ \\
\hline 7 & Нові клієнти за товарною групою & Б.Б. Каргін \\
\hline 8 & Кількість чи частка втрачених клієнтів & $\begin{array}{l}\text { Н.М. Головай, Б.Б. Каргін, } \\
\text { Г.Й. Островська, І.В. Пономарьова, } \\
\text { І.В. Ярошенко }\end{array}$ \\
\hline 9 & $\begin{array}{c}\text { Кількість чи частка корпоративних клієнтів- } \\
\text { підприємств } \\
\end{array}$ & Ю.О. Лецер \\
\hline 10 & $\begin{array}{c}\text { Кількість чи частка індивідуальних } \\
\text { клієнтів-підприємств }\end{array}$ & Ю.О. Лецер \\
\hline 11 & Кількість чи частка клієнтів - фізичних осіб & Ю.О. Лецер \\
\hline 12 & Кількість укладених договорів з кліснтами & Н.М. Головай \\
\hline 13 & $\begin{array}{c}\text { Кількість повторно укладених договорів } 3 \\
\text { клієнтами }\end{array}$ & Н.М. Головай \\
\hline 14 & Частка договорів з попередньою оплатою & О.В. Ачкасова \\
\hline 15 & Відсоток повторних покупок & Н.М. Андрієнко \\
\hline 16 & Ступінь утримання клієнтів & Н.М. Андрієнко \\
\hline 17 & $\begin{array}{c}\text { Коефіцієнт збереження } \\
\text { стратегічно важливих клієнтів }\end{array}$ & А.В. Штереверя \\
\hline
\end{tabular}

Наявні в інформаційній системі підприємства дані про структуру клієнтської бази, зміни як в загальній кількості, так і в окремих групах клієнтів (наприклад, корпоративні клієнти-підприємства, індивідуальні клієнти-підприємства, клієнти фізичні особи), відсоток повторних покупок, оформлені нові договори чи повторно оформлені за певні періоди - це все коло уваги показників перспективи «Клієнти», що характеризують клієнтську базу підприємства. Дані показники здебільшого розраховуються на основі вже наявної інформації про зафіксовані угоди 3 клієнтами, що занесена до інформаційної бази підприємства.

Третя група - показники, що характеризують рівень задоволеності клієнтів підприємства (табл. 5).

Таблиия 5

Показники перспективи «Клієнти», щуо характеризують рівень задоволеності клієнтів підприємства

\begin{tabular}{|c|c|c|}
\hline $\begin{array}{l}\text { № } \\
3 / n\end{array}$ & Показник & $\begin{array}{c}\text { Автори, які пропонують показник до } \\
\text { використання }\end{array}$ \\
\hline 1 & $\begin{array}{l}\text { Індекс (коефіцієнт, рівень, показник, ступінь) } \\
\text { задоволеності клієнтів }\end{array}$ & $\begin{array}{l}\text { Н.М. Андрієнко, Н.М. Головай, } \\
\text { М.М. Іваннікова, Б.Б. Каргін, І.В. Науменко, } \\
\text { Г.Й. Островська, С.В. Поліщук, } \\
\text { І.В. Пономарьова, С.О. Фаізова, А.В. Шайкан, } \\
\text { І.В. Шварц }\end{array}$ \\
\hline 2 & $\begin{array}{l}\text { Рівень задоволення споживачів } \\
\text { продукції }\end{array}$ & В.I. Лемішковський \\
\hline 3 & Рівень прихильності споживачів & М.М. Іваннікова \\
\hline 4 & Рівень обслуговування (сервісу) клієнтів & О.О. Курносова, І.В. Ярошенко \\
\hline 5 & $\begin{array}{l}\text { Частка запитів клієнтів, незадоволених } 31 \\
\text { разу }\end{array}$ & С.В. Поліщук \\
\hline 6 & $\begin{array}{l}\text { Частка клієнтів, задоволених співпрацею } 3 \\
\text { підприємством }\end{array}$ & І.М. Ягнюк \\
\hline 7 & Задоволеність часом доставки & А.В. Шайкан \\
\hline
\end{tabular}


Закінчення табл. 5

\begin{tabular}{|c|l|l|}
\hline 8 & Кількість чи частка рекламацій & $\begin{array}{l}\text { Н.М. Андріснко, М.В. Височина, } \\
\text { М.М. Іваннікова, І.В. Науменко, } \\
\text { I.В. Пономарьова }\end{array}$ \\
\hline 9 & Кількість скарг & М.В. Височина, Г.Й. Островська, А.В. Шайкан \\
\hline 10 & Кількість повернень & Г.Й. Островська, А.В. Шайкан \\
\hline 11 & Кількість позитивних відгуків & А.В. Шайкан \\
\hline 12 & Кількість скасованих замовлень товару & А.В. Шайкан \\
\hline
\end{tabular}

Зазначена група показників характеризує ступінь задоволення чи незадоволення клієнтів співпрацею 3 підприємством. Через такі інструменти зворотного зв’язку, як відгуки, підприємство може дізнатися про думки власних клієнтів задля врахування цього в подальшому розвитку. Найпоширенішим в межах цієї групи є такі показники, які можуть називатися індексом (коефіцієнтом, рівнем, показником, ступенем) задоволеності клієнтів, при цьому їх розрахунок не обов'язково є аналогічним, однаковим чи схожим. Для отримання необхідної інформації про ступінь задоволеності споживачів можна використовувати різні методи статистики, проведення анкетування та опитування, кваліфікований персонал для обробки інформації [23, с. 73].

Четверта група - показники, що характеризують особливості пропозиції підприємства (табл. 6).

Таблиия 6

Показники перспективи «Клієнти», щчо характеризують особливості пропозиџї підприємства

\begin{tabular}{|c|c|c|}
\hline $\begin{array}{l}№ \\
3 / n\end{array}$ & Показник & $\begin{array}{c}\text { Автори, які пропонують показник } \\
\text { до використання }\end{array}$ \\
\hline 1 & Частка нових продуктів & $\begin{array}{l}\text { О.В. Ачкасова, Р.О. Побережний, } \\
\text { І.В. Ярошенко }\end{array}$ \\
\hline 2 & Частка сертифікованої продукції & В.І. Вострякова \\
\hline 3 & Асортиментність & I.В. Шварц \\
\hline 4 & Частка якісної продукції & В.I. Лемішковський \\
\hline 5 & $\begin{array}{l}\text { Частка продукції, що підлягає гарантійному } \\
\text { обслуговуванню в структурі загального обсягу } \\
\text { виготовленої продукції }\end{array}$ & О.В. Мінєнкова \\
\hline 6 & Рівень обслуговування (в т. ч. сервісного) & М.В. Височина, О.О. Курносова \\
\hline 7 & Коефіцієнт (рівень) конкурентоспроможності продукції & $\begin{array}{l}\text { М.В. Височина, С.О. Фаізова, } \\
\text { А.В. Штереверя }\end{array}$ \\
\hline 8 & Індекс комерційно-технологічної гнучкості компанії & Н.М. Андрієнко \\
\hline 9 & Рівень ціни стосовно середнього по галузі & I.В. Ярошенко \\
\hline 10 & $\begin{array}{l}\text { Відношення ціни продукції до фіксованої ціни на } \\
\text { поточну продукцію }\end{array}$ & О.В. Мінєнкова \\
\hline 11 & Зіставність ціни та якості товару / послуги & М.В. Височина, М.М. Іваннікова \\
\hline 12 & Частота перегляду цін & М.В. Височина \\
\hline 13 & Частка відшкодувань і знижок & М.В. Височина \\
\hline 14 & Час, необхідний для виконання замовлення & М.В. Височина, А.В. Шайкан \\
\hline 15 & Час, витрачений на один контакт з клієнтом & А.В. Шайкан \\
\hline 16 & $\begin{array}{l}\text { Кількість властивостей продукту, що перевищують ті, } \\
\text { які є у конкурентів }\end{array}$ & А.В. Шайкан \\
\hline 17 & Рівень ідентифікації (впізнаваності) товару / бренда & Н.М. Андрієнко, Г.В. Малахівська \\
\hline 18 & Прихильність клієнта до товарів компанії & М.В. Височина \\
\hline 19 & Рівень поінформованості зацікавлених сторін & I.В. Ярошенко \\
\hline 20 & $\begin{array}{l}\text { Відсоток присутності в спеціалізованих рекламних } \\
\text { виданнях }\end{array}$ & I.В. Ярошенко \\
\hline 21 & $\begin{array}{l}\text { Кількість чи частка вчасно доставлених (виконаних) } \\
\text { замовлень продукції }\end{array}$ & $\begin{array}{l}\text { М.В. Височина, М.М. Іваннікова, } \\
\text { В.І. Лемішковський, С.В. Поліщук, } \\
\text { А.В. Шайкан, А.В. Штереверя }\end{array}$ \\
\hline 22 & $\begin{array}{l}\text { Комплексний } \quad \text { показник } \\
\text { зобов'язань (асортимент, якість, строки постачання) }\end{array}$ & А.В. Штереверя \\
\hline 23 & Час доставки готової продукції & В.І. Вострякова \\
\hline 24 & Середній термін обробки та виконання замовлення & М.М. Іваннікова, А.В. Шайкан \\
\hline 25 & Середній час затримки поставок за місяць & І.В. Пономарьова \\
\hline
\end{tabular}


Запропоновані показники, що характеризують особливості пропозиції підприємства, спрямовані на розкриття даних про асортимент, якість продукції, своєчасність виконання замовлень, доставки до адресатів, рівень ідентифікації товару чи бренда, поширення інформації в різних джерелах (3МI, друковані видання тощо). Все це демонструє специфіку як самої продукції підприємства, так і процесів, що супроводжують повне виконання угоди перед клієнтом, в т. ч. і діяльність підприємства, спрямовану на увагу клієнта.

П’ята група - показники, що характеризують надходження / видатки, що прямо чи опосередковано пов’язані з клієнтами, та ефективність використання клієнтського капіталу (табл. 7).

Таблиия 7

Показники перспективи «Клієнти», щзо характеризують надходження / видатки, пов 'язані з клієнтами, та ефективність використання клієнтського капіталу підприємства

\begin{tabular}{|c|c|c|}
\hline $\begin{array}{l}\text { № } \\
3 / n\end{array}$ & Показник & $\begin{array}{c}\text { Автори, які пропонують показник } \\
\text { до використання }\end{array}$ \\
\hline 1 & Витрати на рекламу & Н.М. Головай, Н.О. Іванченко \\
\hline 2 & Представницькі витрати & Н.М. Головай \\
\hline 3 & Витрати на маркетинг & Н.М. Головай \\
\hline 4 & Витрати на маркетинг на 1 робітника & I.В. Ярошенко \\
\hline 5 & $\begin{array}{l}\text { Витрати на функціонування маркетингової інформаційної } \\
\text { системи }\end{array}$ & М.В. Височина \\
\hline 6 & Витрати на залучення нового покупця & А.В. Шайкан \\
\hline 7 & Витрати на обслуговування клієнта & I.В. Ярошенко \\
\hline 8 & Витрати на розробку та обслуговування вебсайту & Н.О. Іванченко \\
\hline 9 & Витрати на дослідження & О.В. Ачкасова \\
\hline 10 & $\begin{array}{l}\text { Частка витрат на просування } \\
\text { собівартості товару }\end{array}$ & О.В. Мінєнкова \\
\hline 11 & Частка витрат на гарантійне обслуговування & О.В. Мінєнкова \\
\hline 12 & Частка витрат, що не створюють цінність & І.В. Ярошенко \\
\hline 13 & Рентабельність витрат на маркетинг & Н.М. Головай \\
\hline 14 & Співвідношення виручки та витрат на маркетинг & М.М. Іваннікова \\
\hline 15 & $\begin{array}{l}\text { Відношення витрат на просування продукції до виручки } \\
\text { (прибутку) }\end{array}$ & Б.Б. Каргін \\
\hline 16 & Обсяг збуту & М.В. Височина \\
\hline 17 & Надходження від реалізації & I.В. Пономарьова \\
\hline 18 & Дохід & М.В. Височина \\
\hline 19 & Виручка від існуючих клієнтів & Г.Й. Островська \\
\hline 20 & Обсяг реалізації продукції по галузі & Н.М. Головай \\
\hline 21 & Критичний обсяг реалізації & I.В. Науменко, А.В. Штереверя \\
\hline 22 & Обсяг продажів на 1 клієнта & О.В. Ачкасова, І.В. Ярошенко \\
\hline 23 & Обсяг чи частка продажів постійним клієнтам & $\begin{array}{l}\text { Г.Й. Островська, A.В. Шайкан, } \\
\text { I.М. Ягнюк }\end{array}$ \\
\hline 24 & Обсяг повторних продажів & М.М. Іваннікова \\
\hline 25 & $\begin{array}{l}\text { Частка продажів новим клієнтам у загальному обсязі } \\
\text { продажів за товарною групою }\end{array}$ & Б.Б. Каргін \\
\hline 26 & Частка продажів з відсутністю рекламацій & І.М. Ягнюк \\
\hline 27 & Частка продажів без відхилень по строкам поставок & I.М. Ягнюк \\
\hline 28 & Частка продажів екологічно чистої продукції & І.В. Ярошенко \\
\hline 29 & Доход від залучення нових клієнтів & Н.О. Іванченко \\
\hline 30 & Збитки від втрати постійних клієнтів & Н.О. Іванченко \\
\hline 31 & Прибутковість споживача & А.В. Шайкан \\
\hline 32 & $\begin{array}{l}\text { Середня прибутковість від } 1 \text { споживача за } 1 \text { операцію, } \\
\text { порівняно } 3 \text { середніми витратами на } 1 \text { операцію }\end{array}$ & А.В. Шайкан \\
\hline 33 & Коефіцієнт рентабельності каналу розподілу & А.В. Штереверя \\
\hline 34 & Середній час життя клієнта & I.В. Ярошенко \\
\hline 35 & $\begin{array}{l}\text { Коефіцієнт еластичності продажу за витратами на } \\
\text { комунікації }\end{array}$ & Н.М. Головай \\
\hline 36 & Коефіцієнт комунікаційної ємності & Н.М. Головай \\
\hline 37 & Індекс споживчої вартості (Customer Value Index, CVI) & Н.М. Андрієнко, Г.Й. Островська \\
\hline
\end{tabular}


Група показників, наведена в таблиці 7, містить показники, які виражаються через витрати, доходи, прибутки, збитки, відношення цих категорій для розуміння ефекту (наприклад, частка витрат на просування товарів у структурі собівартості товару), та показники, що описують ефективність використання клієнтського капіталу підприємства. Клієнтський капітал як складова інтелектуального капіталу має відображатися в фінансовій та нефінансовій звітності через такі об'єкти, як нематеріальні активи, але в реальній обліковій практиці сучасних підприємств не всі клієнтські ресурси відображаються в таких звітах. До клієнтських ресурсів належать інформаційні, репутаційні, договірні та особистісні ресурси, що утворюються на основі ефективних відносин з клієнтами підприємства, та мають здатність спричиняти певний ефект, зокрема створювати додану вартість для підприємства. Наприклад, індекс споживчої вартості (Customer Value Index, CVI) - це показник, який розраховується на основі кількісних і якісних показників, що характеризують співвідношення цін компанії та цін найближчих конкурентів, а також на основі аналізу та співвідношення споживчої корисності продукції для клієнта, їі ціни, якості обслуговування. Показники цієї групи зосереджені на отримуваних чи недоотримуваних ефектах співпраці 3 клієнтами, що безпосередньо впливають на фінансові результати діяльності підприємства.

В таблиці 8 наведено загальне групування показників перспективи «Клієнти», що побудоване на основі узагальнення даних таблиць 3-7.

Групування показників перспективи «Клієнти»*

Таблиия 8

\begin{tabular}{|c|c|c|}
\hline $\begin{array}{l}\text { № } \\
3 / n\end{array}$ & Група показників & Напрям використання (стратегічні иілі) \\
\hline 1 & $\begin{array}{c}\text { Показники, що } \\
\text { характеризують позицію } \\
\text { підприємства на ринку } \\
\end{array}$ & $\begin{array}{l}\text { Здебільшого використовуються для реалізації } \\
\text { стратегічної цілі, як «Збільшення частки ринку» }\end{array}$ \\
\hline 2 & $\begin{array}{c}\text { Показники, що } \\
\text { характеризують клієнтську } \\
\text { базу підприємства } \\
\end{array}$ & 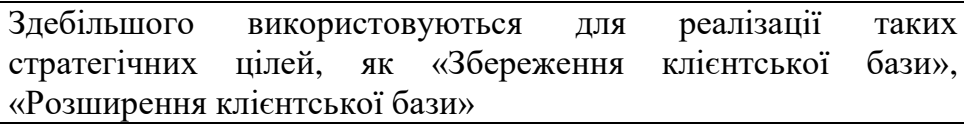 \\
\hline 3 & $\begin{array}{c}\text { Показники, що } \\
\text { характеризують рівень } \\
\text { задоволеності клієнтів } \\
\text { підприємства }\end{array}$ & $\begin{array}{l}\text { Можуть використовуватися для реалізації різних стратегічних } \\
\text { цілей, наприклад, «Задоволення потреб клієнта», «Вчасне і } \\
\text { якісне виконання замовлень клієнтів», «Підтримка якісної } \\
\text { взаємодії } 3 \text { клієнтами», «Забезпечення зручного механізму } \\
\text { зворотного зв’язку } 3 \text { клієнтами», «Врахування інтересів } \\
\text { клієнтів в подальшому удосконаленні продукту», «Підвищення } \\
\text { рівня лояльності клієнтів» }\end{array}$ \\
\hline 4 & $\begin{array}{c}\text { Показники, що } \\
\text { характеризують особливості } \\
\text { пропозиції підприємства }\end{array}$ & $\begin{array}{l}\text { Можуть використовуватися для реалізації різних стратегічних } \\
\text { цілей, наприклад, «Підвищення сили бренда», «Зростання } \\
\text { лояльності до бренда», «Збільшення обсягів продажів за } \\
\text { рахунок розширення асортименту», «Збільшення обсягів } \\
\text { продажів за рахунок підвищення якості продукції», } \\
\text { «Забезпечення більш високого рівня комплексності } \\
\text { пропозиції» }\end{array}$ \\
\hline 5 & $\begin{array}{c}\text { Показники, що } \\
\text { характеризують } \\
\text { надходження/видатки, } \\
\text { пов’язані з клієнтами, та } \\
\text { ефективність використання } \\
\text { клієнтського капіталу } \\
\text { підприємства }\end{array}$ & $\begin{array}{l}\text { Можуть використовуватися для реалізації різних стратегічних } \\
\text { цілей, наприклад «Зростання прибутковості клієнта», } \\
\text { «Збільшення ефективності витрат на просування продукції», } \\
\text { «Оптимізація витрат на збут продукції», «Оптимізація витрат } \\
\text { на залучення одного нового клієнта» }\end{array}$ \\
\hline
\end{tabular}

Таке групування показників перспективи «Клієнти» дозволяє структурувати бачення характеру показників, що розглядаються як ефективні інструменти в межах реалізації ЗСП задля досягнення обраних стратегічних цілей.

1.4. Стратегічні ініціативи (заходи) перспективи «Клієнти». Наступним елементом перспективи «Клієнти» в межах використання ЗСП є стратегічні ініціативи чи заходи, які прямо чи опосередковано підпорядковані обраним цілям та узгоджуються в управлінні з відповідними показниками. Між стратегічними цілями та стратегічними ініціативи може бути проміжна ланка у вигляді завдань, підпорядкованих цілям та більш тісно пов'язаних з необхідними ініціативами чи заходами, але в межах 
цього дослідження такі завдання не враховуються. Стратегічні ініціативи $є$ «інструкцією» для виконавців у вигляді рекомендованої програми дій. Приклади стратегічних ініціатив (заходів) перспективи «Кліснти» чи тих, які безпосередньо відповідають за відносини з кліснтами, наведено в таблиці 9.

Таблиця 9

Приклади стратегічних ініч̨іатив перспективи «Клієнти» в межах реалізаиії ЗСП

\begin{tabular}{|c|c|c|}
\hline № $3 / n$ & Автор & Стратегічні ініціативи \\
\hline 1 & $\begin{array}{l}\text { Н.М. Андрієнко } \\
\text { [1, с. 144] }\end{array}$ & $\begin{array}{l}\text { - стимулювання первинного попиту; } \\
\text { - підвищення інтенсивності споживання; } \\
\text { - залучення покупців конкурентів }\end{array}$ \\
\hline 2 & $\begin{array}{l}\text { В.І. Вострякова } \\
\quad[4, \text { с. } 158]\end{array}$ & $\begin{array}{l}\text { - впровадження ERP (інформаційна система планування ресурсів } \\
\text { підприємства); } \\
\text { - сертифікація відповідно до вимог } Є \mathrm{C}\end{array}$ \\
\hline 3 & $\begin{array}{l}\text { Н.М. Головай } \\
{[5, \text { с. } 165]}\end{array}$ & $\begin{array}{l}\text { - розробка програми навчання персоналу та здійснення необхідних } \\
\text { інвестицій; } \\
\text { - забезпечення постійного зв’язку } 3 \text { покупцями через створення } \\
\text { вебсайту, Інтернет-магазину; } \\
\text { - постійне повідомлення покупців про заплановані заходи; } \\
\text { - збір необхідної інформації про наявних клієнтів та її систематизація }\end{array}$ \\
\hline 4 & $\begin{array}{l}\text { B.I. Лемішковський } \\
{[13, \text { с. } 145]}\end{array}$ & $\begin{array}{l}\text { - розширення і захист ринків збуту; } \\
\text { - підвищення якості виробленої продукції }\end{array}$ \\
\hline 5 & $\begin{array}{l}\text { Г.Й. Островська } \\
{[19, \text { с. } 168]}\end{array}$ & $\begin{array}{l}\text { - дотримання якісних параметрів продукту; } \\
\text { - підтримка рівня обслуговування }\end{array}$ \\
\hline 6 & $\begin{array}{l}\text { I.В. Пономарьова } \\
{[23, \text { с. } 72,178]}\end{array}$ & $\begin{array}{l}\text { - завоювання у споживачів репутації надійного постачальника за } \\
\text { якістю та дотриманням термінів постачання продукції; } \\
\text { - розширення асортименту продукції; } \\
\text { - підвищення конкурентоспроможності за рахунок випередження } \\
\text { конкурентів за зменшенням витрат; } \\
\text { - збільшення рентабельності та суми чистого прибутку; } \\
\text { - лідерство серед конкурентів у виробництві аналогічної продукцї; } \\
\text { - застосування перспективних маркетингових можливостей; } \\
\text { - оновлення виробничих потужностей підприємства; } \\
\text { - доставка продукції за кошти виробника; } \\
\text { - зниження частки попередньої оплати для постійних клієнтів; } \\
\text { - гнучка система знижок для постійних клієнтів }\end{array}$ \\
\hline
\end{tabular}

У випадку дотримання принципу, що стратегічні ініціативи перспективи «Клієнти» мають бути орієнтиром реалізації стратегічних цілей, слід зазначити, що ініціативи мають конкретизувати дії управлінців. Так розширення і захист ринків збуту (В.І. Лемішковський) є стратегічною ціллю, а не ініціативою. Така плутанина зустрічається і в інших роботах. Задля уникнення випадків виникнення таких двозначностей, на нашу думку, необхідно в процесі вибору ініціатив для реалізації стратегічних цілей вносити більше конкретики у їх сутнісне наповнення. Наприклад, стратегічна ціль - це розширення частки ринку, відповідно, стратегічними ініціативами можуть бути такі заходи, як стимулювання первинного попиту, підвищення інтенсивності споживання, залучення покупців конкурентів.

Різноманіття стратегічних ініціатив буде зумовлено специфікою діяльності підприємства та обраною стратегією. Іноді обрані ініціативи не виправдовують себе в процесі досягнення поставлених цілей, тому управлінці можуть змінювати їх на інші, що ще раз підтверджує адаптивність використання ЗСП в управлінні підприємствами.

Інформація в дисертаційних дослідженнях щодо стратегічних ініціатив має нечіткий характер, тому зауважимо, що, на відміну від стратегічних цілей, обрані ініціативи повинні мати конкретний характер сукупності дій для реалізації цілі, до якої вони підпорядковані.

1.5. Інформаційне забезпечення управління в межах використання ЗСП. Реалізація практики ЗСП передбачає використання інформаційних носіїв у вигляді певних документів, звітів. Хоча об'єктом уваги цієї роботи є перспектива «Клієнти», ми не можемо частково розглядати інформаційне забезпечення лише відносно вказаної перспективи, тому маємо досліджувати це питання в цілому по всій ЗСП. Приклади пропозицій дослідників відносно удосконалення системи інформаційного забезпечення управління в межах використання ЗСП наведено в таблиці 10. 
Таблиия 10

Удосконалення системи інформаційного забезпечення управління в рамках використання ЗСП

\begin{tabular}{|c|c|c|c|}
\hline $\begin{array}{l}\text { № } \\
\text { 3/n }\end{array}$ & Автор & $\begin{array}{c}\text { Пропозичї } \\
\text { до використання }\end{array}$ & Характеристика \\
\hline 1 & $\begin{array}{l}\text { Н.М. Головай } \\
{[5, \text { с. } 165]}\end{array}$ & $\begin{array}{c}\text { Стратегічна карта } \\
\text { підприємства в частині } \\
\text { розвитку інтелектуального } \\
\text { капіталу } \\
\end{array}$ & $\begin{array}{l}\text { Містить в розрізі стратегічних цілей таку } \\
\text { інформацію, як обрані показники, їх економічний } \\
\text { зміст, завдання та рекомендовану програму дій }\end{array}$ \\
\hline 2 & $\begin{array}{l}\text { Н.О. Іванченко } \\
{[8, \text { с. } 142-143]}\end{array}$ & $\begin{array}{c}\text { Звіт «Про рух } \\
\text { нематеріальних активів» }\end{array}$ & $\begin{array}{l}\text { Містить показники про особливості відносин } \\
\text { клієнтами та позицію підприємства на ринку за } \\
\text { розділами. Наприклад, ринок і конкуренція (постійні } \\
\text { конкуренти; нові конкуренти; витрати на рекламу); } \\
\text { фактори, які сприяють успішній роботі підприємства } \\
\text { (політика знижок; індивідуальний підхід до клієнта; } \\
\text { умови контрактів), навички і неформалізовані знання } \\
\text { (маркетингові дослідження; інвестиції в дослідження } \\
\text { нових ринків), групи клієнтів та їх потреби (нові } \\
\text { клієнти; клієнти, що відмовилися від співпраці; } \\
\text { постійні клієнти) }\end{array}$ \\
\hline \multirow{3}{*}{3} & \multirow{3}{*}{$\begin{array}{l}\text { Т.М. Мельник } \\
{[16, \text { с. } 142 \text {, }} \\
\text { 252-253] }\end{array}$} & $\begin{array}{c}\text { Звіт про виконання } \\
\text { цільових значень } \\
\text { ключових показників } \\
\text { результативності (КПР) у } \\
\text { межах реалізації } \\
\text { інвестиційного проєкту } \\
\end{array}$ & $\begin{array}{l}\text { Містить показники, структуровані за } \\
\text { перспективами (в т. ч. перспективою «Клієнти»), та } \\
\text { їх цільові, реальні значення та відхилення реальних } \\
\text { від цільових значень }\end{array}$ \\
\hline & & $\begin{array}{l}\text { Звіт про виконання } \\
\text { цільових значень КПР } \\
\text { підрозділом }\end{array}$ & $\begin{array}{l}\text { На рівні окремого підрозділу (PR-департамент, } \\
\text { департамент франчайзингу, відділ маркетингу) } \\
\text { аналогічно складається такий звіт }\end{array}$ \\
\hline & & Картка КПР & $\begin{array}{l}\text { Містить код КПР, назву перспективи, стратегічну } \\
\text { ціль, підрозділ, а також інформацію щодо формули } \\
\text { розрахунку КПР, його інформаційних джерел, } \\
\text { періодичності розрахунку та цільового значення }\end{array}$ \\
\hline 4 & $\begin{array}{l}\text { I.В. Науменко } \\
{[18, \text { с. } 149,183]}\end{array}$ & $\begin{array}{c}\text { Картка робітника - Картка } \\
\text { бригади - Картка дільниці } \\
\text { - Картка цеху - Картка } \\
\text { відділу - Картка } \\
\text { підприємства }\end{array}$ & $\begin{array}{l}\text { Відповідно до вказаної підпорядкованості } \\
\text { створюється інформаційна модель управління } \\
\text { підприємством на основі ЗСП. Така документація } \\
\text { допоможе відслідковувати, як виконується план і } \\
\text { вчасно усувати причини, що призводять до } \\
\text { невиконання плану. Наприклад, в рахунковій карті } \\
\text { цеху за перспективами ЗСП вказуються напрями } \\
\text { діяльності, цілі і показники }\end{array}$ \\
\hline 5 & $\begin{array}{l}\text { Г.Й. Островська } \\
{[19, \text { с. } 166-167]}\end{array}$ & $\begin{array}{c}\text { Звіт з позиції управління } \\
\text { вартістю }\end{array}$ & $\begin{array}{l}\text { Містить інформацію про результати діяльності } \\
\text { підприємства, пропущену через призму інтеграції } \\
\text { концепції управління вартістю та ЗСП }\end{array}$ \\
\hline \multirow{3}{*}{6} & \multirow{3}{*}{$\begin{array}{l}\text { С.В. Поліщук } \\
{[22, \text { с. } 201,203 \text {, }} \\
210]\end{array}$} & $\begin{array}{l}\text { Зведений бюджет доходів } \\
\text { та витрат }\end{array}$ & $\begin{array}{l}\text { Містить інформацію щодо взаємозв'язку зі } \\
\text { стратегічними цілями в розрізі перспектив (в т. ч. } \\
\text { «Клієнти»), а саме значення визначених показників } \\
\text { перспектив }\end{array}$ \\
\hline & & $\begin{array}{c}\text { Організаційний регламент } \\
\text { інтегрованого } \\
\text { бюджетування } \\
\end{array}$ & $\begin{array}{l}\text { Містить інформацію про порядок формування та } \\
\text { реалізації ЗСП на підприємстві } 3 \text { уточненням } \\
\text { відповідальних за виконання підрозділів }\end{array}$ \\
\hline & & $\begin{array}{c}\text { ЗСП в розрізі плану та } \\
\text { факту }\end{array}$ & $\begin{array}{l}\text { Містить інформацію планових } \\
\text { значень визначених показників в розрізі кожної } \\
\text { перспективи }\end{array}$ \\
\hline \multirow{3}{*}{7} & \multirow{3}{*}{$\begin{array}{l}\text { O.O. Трут } \\
{[26, \text { c. } 311]}\end{array}$} & Стратегічна карта & $\begin{array}{l}\text { Такі карти характеризують напрямок руху і його } \\
\text { причину }\end{array}$ \\
\hline & & Карта показників & $\begin{array}{l}\text { Такі карти відображають успішність цього руху і } \\
\text { допомагають }\end{array}$ \\
\hline & & Бюджет & $\begin{array}{l}\text { Врахування цього документа під час реалізації } \\
\text { стратегічних цілей є обов'язковим } 3 \text { огляду на } \\
\text { можливості підприємства }\end{array}$ \\
\hline
\end{tabular}


Закінчення табл. 10

\begin{tabular}{|c|c|c|c|}
\hline 8 & $\begin{array}{l}\text { С.О. Фаізова } \\
{[27, \text { с. } 83]}\end{array}$ & $\begin{array}{c}\text { Шаблон ЗСП } \\
\text { «Збалансована система } \\
\text { показників вартісно } \\
\text { орієнтованого } \\
\text { підприємства за моделлю } \\
\text { інноваційного лідерства» } \\
\end{array}$ & $\begin{array}{l}\text { В розрізі різних проєкцій наводиться інформація } \\
\text { щодо визначених стратегічних цілей; цінностей, } \\
\text { що створюються; ключових факторів вартості; } \\
\text { відповідних показників }\end{array}$ \\
\hline \multirow[t]{2}{*}{9} & \multirow[t]{2}{*}{$\begin{array}{l}\text { А.В. Шайкан } \\
{[28, \text { с. 266] }}\end{array}$} & $\begin{array}{c}\text { Інформаційна картка } \\
\text { показника ЗСП }\end{array}$ & $\begin{array}{l}\text { Містить назву показника, код показника в системі } \\
\text { кодування підприємства, дату початку розрахунків, } \\
\text { періодичність розрахунку, дату надання } \\
\text { користувачу, відповідальну особу за розрахунок, } \\
\text { зміст показника, метод розрахунку }\end{array}$ \\
\hline & & Журнал & Містять карти всіх показників ЗСП \\
\hline \multirow[t]{2}{*}{10} & \multirow[t]{2}{*}{$\begin{array}{l}\text { А.В. Штереверя } \\
{[30, \text { с. } 139,177]}\end{array}$} & $\begin{array}{c}\text { Стратегічна карта } \\
\text { корпоративного рівня }\end{array}$ & 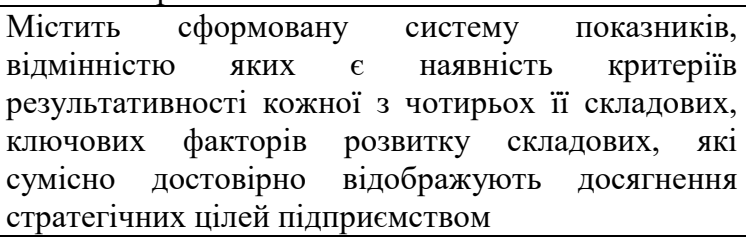 \\
\hline & & $\begin{array}{c}\text { Стратегічна карта окремих } \\
\text { підрозділів }\end{array}$ & $\begin{array}{l}\text { Аналогічно } \\
\text { підприємства }\end{array}$ \\
\hline
\end{tabular}

Загальновідомим варіантом для інформаційного забезпечення ЗСП на підприємстві $є$ побудова стратегічних карт. Такі стратегічні карти пропонують формувати як для підприємства в цілому, так і для окремих його підрозділів. Як зазначає О.О. Трут, стратегічні карти схожі з географічними картами, які наочно зображають шлях, який потрібно виконати з пункту А (теперішні можливості організації, структура і мета) в пункт Б (майбутній бажаний стан організації, відображений в баченні, місії і стратегічному плані). Карти показників дозволяють менеджерам i командам співробітників орієнтуватися в часі та просторі й управляти рухом організації [26, с. 304]. Стратегічні карти підприємства мають будуватися на основі стратегічних карт нижнього порядку, які, в свою чергу, будуються на картах ще нижчого порядку (наприклад, на картах бригади чи робітника). Дотримання визначеної ієрархії дозволить реалізовуватися принципу залученості всіх працівників до процесів реалізації стратегії по підприємству. Також необхідно складати картки за обраними показниками ЗСП задля моніторингу їх реальних значень, контролю за їх відхиленнями від запланованих значень та відповідної корекції цільових значень у разі необхідності. Підхід розбивки інформаційних форм за перспективами ЗСП використовується не тільки в стратегічних картах, але й в інших формах звітності.

1.6. Інтеграція ЗСП з іншими підходами в управлінні. На думку деяких дослідників, використання ЗСП в інтеграції з іншими управлінськими практиками збільшують можливості подібного управління, наприклад, завдяки створенню певного синергетичного ефекту. В таблиці 11 наведено пропозиції використання ЗСП в інтеграції з іншими підходами в управлінні.

Пропозицї використання ЗСП інтегровано з іншими підходами в управлінні

Табличя 11

\begin{tabular}{|c|c|c|}
\hline № $3 / n$ & Автор & Пропозииіï \\
\hline 1 & $\begin{array}{c}\text { М.М. Іваннікова } \\
\text { [7, с. 160] }\end{array}$ & $\begin{array}{l}\text { Зміст синергічного ефекту між елементами сучасної концепції } \\
\begin{array}{l}\text { маркетингу взаємовідносин } \\
\text { застосуванням ЗСП }\end{array}\end{array}$ \\
\hline 2 & $\begin{array}{l}\text { М.В. Кадничанський } \\
{[9, \text { с. 96] }}\end{array}$ & Використання ЗСП і вартісно орієнтованого управління \\
\hline 3 & $\begin{array}{c}\text { B.I. Лемішковський } \\
{[13, \text { с. 158] }}\end{array}$ & $\begin{array}{l}\text { Інтеграція концепції ЗСП та показника EVA передбачає, що для } \\
\text { отримання синергетичного ефекту EVA розглядається ключовим } \\
\text { під час формування фінансової проєкції ЗСП }\end{array}$ \\
\hline 4 & $\begin{array}{l}\text { Ю.О. Лецер } \\
{[14, \text { с. } 58]}\end{array}$ & $\begin{array}{l}\text { ЗСП підприємства може бути побудована } 3 \text { шаблоном бізнес- } \\
\text { моделі Остервальдера на основі шаблонів О.Гассамана }\end{array}$ \\
\hline 5 & $\begin{array}{l}\text { Г.В. Малахівська } \\
{[15, \text { с. } 226]}\end{array}$ & $\begin{array}{l}\text { Поєднання ЗСП і управління відносинами з клієнтами (Customer } \\
\text { Relationship Management, CRM) }\end{array}$ \\
\hline 6 & $\begin{array}{l}\text { Г.Й. Островська } \\
{[19, \text { с. } 66-67]}\end{array}$ & Використання ЗСП і вартісно орієнтованого управління \\
\hline 7 & $\begin{array}{l}\text { O.O. Tpyт } \\
{[26, \text { c. } 94]}\end{array}$ & $\begin{array}{l}\text { Використання ЗСП і вартісно орієнтованого управління (в т. ч. } \\
\text { EVA) }\end{array}$ \\
\hline
\end{tabular}


Закінчення табл. 11

\begin{tabular}{|c|c|c|}
\hline 8 & $\begin{array}{l}\text { С.О. Фаізова } \\
{[27, \text { с. } 61]}\end{array}$ & $\begin{array}{l}\text { Наголошується на необхідності інтеграції концепцій VBM та ЗСП, } \\
\text { що здійснюється через фінансову панель управління } \\
\text { підприємством та використовує VBM-показники. Точкою } \\
\text { перетину VBM та ЗСП, по-перше, є єдина стратегічна мета - } \\
\text { зростання ринкової вартості підприємства }\end{array}$ \\
\hline 9 & $\begin{array}{l}\text { А.В. Шайкан } \\
{[28, \text { с. 407] }}\end{array}$ & $\begin{array}{l}\text { Інтеграція ЗСП з моделлю EVA і обліком витрат за видами } \\
\text { діяльності }(\mathrm{ABC})\end{array}$ \\
\hline 10 & $\begin{array}{l}\text { I.Й. Яремко } \\
{[32, \text { с. } 294]}\end{array}$ & $\begin{array}{l}\text { ЗСП як інструментарій супроводу управлінської парадигми, } \\
\text { спрямованої на створення вартості }\end{array}$ \\
\hline
\end{tabular}

Інтеграційні можливості ЗСП доводять високий рівень адаптивності цієї концепції до різних умов господарювання та різних векторів розвитку підприємств. Так, наприклад, ЗСП та вартісно орієнтоване управління чітко доповнюють одне одного, зокрема основна мета вартісно орієнтованого управління прирощення доданої вартості - може бути стратегічною ціллю перспективи «Фінанси» ЗСП. А показник EVA, що є одним з основних показників, що використовуються в межах системи вартісно орієнтованого управління, може бути показником перспективи «Фінанси».

Висновки та перспективи подальших досліджень. Структурне бачення використання ЗСП в управлінні в розрізі іï перспектив формує чіткі орієнтири розвитку бізнесу та розуміння внеску різних сфер діяльності в кінцевий результат, за яким оцінюється ефективність підприємства в цілому. В умовах впливу зовнішнього середовища, наявності конкуренції та необхідності підтримки грошових надходжень, джерелами яких для підприємства $\epsilon$ клієнти, перспектива «Клієнти» $є$ неодмінною складовою в процесах побудови та використання ЗСП в управлінні підприємством. Аналіз тематики дослідження перспективи ЗСП, що відповідає за відносини 3 клієнтами, структурований за такими питаннями, як назва такої перспективи, ііі стратегічні цілі, показники, стратегічні ініціативи, відповідне інформаційне забезпечення управління та інтеграція цієї концепції з іншими підходами в управлінні.

Зважаючи на те, що концепція ЗСП започатковувалася в англомовному середовищі, та що у в Р.С. Каплана та Д.П. Нортона використовувалося слово «Customer», вважаємо найкоректнішим для вживання термін «Клієнти» для позначення перспективи, що відповідає за відносини 3 клієнтами. Стратегічні цілі перспективи «Клієнти» конкретизуються з огляду на специфіку стратегії підприємства та бачення власної місії в середовищі, в якому воно функціонує, але класичний підхід передбачає такі стратегічні цілі, як збільшення частки ринку, збереження клієнтської бази, розширення клієнтської бази, задоволення потреб клієнта, збільшення прибутковості клієнта.

В межах перспективи «Клієнти» пропонуємо використовувати наступне групування показників за ознаками, що характеризують: позицію підприємства на ринку; клієнтську базу підприємства; рівень задоволеності клієнтів підприємства особливості пропозиції підприємства; надходження/видатки, пов'язані з клієнтами, та ефективність використання клієнтського капіталу підприємства. На відміну від стратегічних цілей обрані ініціативи повинні мати конкретний характер сукупності дій для реалізації цілі, до якої вони підпорядковані. Інформаційним забезпеченням використання ЗСП на підприємстві здебільшого є стратегічні карти, що можуть будуватися на різних рівнях підпорядкування, та картки за обраними показниками, що дозволяють моніторити відхилення їх значень від запланованих. Концепція ЗСП має високий рівень адаптивності, що проявляється в ії можливостях інтеграції з іншими підходами в управлінні, зокрема, з системою вартісно орієнтованого управління.

\section{Список використаної літератури:}

1. Андрієнко Н.М. Організаційно-економічне забезпечення ефективного управління комерційною діяльністю промислового підприємства : дис. ... канд. екон. наук : 08.00 .04 / Н.М. Андрієнко ; Інс-т проблем ринку та екон.-екол. досліджень. - Одеса, 2015. - 213 с.

2. Ачкасова O.B. Удосконалення визначення стратегії підприємства в умовах кризи на основі збалансованої системи показників : автореф. дис. на здобуття наук. ступеня канд. екон. наук : 08.00.04 / O.B. Ачкасова ; Харків. нац. екон. ун-т. - Харків, 2011. - 24 с.

3. Височина М.В. Функціонально-орієнтований підхід до оцінювання ефективності управління діяльністю машинобудівного підприємства : дис. ... канд. екон. наук : 08.00 .04 / М.В. Височина ; Нац. акад. природоохорон. та курорт. буд-ва. - Сімферополь, 2007. - 280 с.

4. Вострякова B.I. Удосконалення логістичної системи розподілу продукції сільськогосподарських підприємств : дис. ... канд. екон. наук : 08.00 .04 / B.I. Вострякова ; Він. нац. аграр. ун-т. - Вінниця, 2017. $233 \mathrm{c}$.

5. Головай Н.М. Облік та аналіз в управлінні інтелектуальним капіталом підприємства : дис. ... канд. екон. наук. : 08.00.09 / Н.М. Головай ; Київ. нац. торг.-екон. ун-т. - Київ, 2009. - 204 с. 
6. Жигулін O.A. Напрями удосконалення управління конкурентоспроможністю підприємницьких структур агробізнесу України : дис. ... д-ра екон. наук : 08.00.04 / O.A. Жигулін ; Нац. ун-т біоресурсів і природокор. України. - Київ, 2019. - 480 с.

7. Іваннікова М.М. Маркетинг у формуванні конкурентних переваг підприємства : дис. ... канд. екон. наук : 08.00.04 / М.М. Іваннікова ; Київ. нац. екон. ун-т ім. В.Гетьмана. - Київ, 2016. - 276 с.

8. Іванченко Н.O. Механізм управління нематеріальними активами на підприємствах легкої промисловості : дис. ... канд. екон. наук : 08.00 .04 / Н.О. Іванченко ; Київ. нац. ун-т технологій та дизайну. - К., 2007. - 187 с.

9. Кадничанський М.B. Організаційно-економічний механізм корпоративного управління будівельних холдингових компаній за збалансованою системою показників : дис. ... канд. екон. наук : $08.00 .04 /$ М.В. Кадничанський. ; Харк. нац. акад. міськ. госп-ва. - Харків, 2009. - 151 с.

10. Каплан Р.С. Сбалансированная система показателей. От стратегии к действию / Р.С. Каплан, Д.П. Нортон ; пер. с англ. - М. : ЗАО «Олимп-Бизнес», 2003. - 304 с.

11. Каргін Б.Б. Впровадження інноваційних інформаційних технологій у діяльність промислових підприємств : дис. ... канд. екон. наук : 08.00.04 / Б.Б. Каргін ; ДВНЗ «Приазов. держ. техн. ун-Т». - Маріуполь, 2019. - 242 с.

12. Курносова O.A. Управление развитием предприятий на основе процессных инноваций : дис. ... канд. экон. наук : 08.00 .04 / O.А. Курносова ; Донецк. нац. ун-т. - Донецк, 2010. -293 с.

13. Лемішковський B.I. Розвиток контролінгової діяльності машинобудівних підприємств : дис. ... канд. екон. наук : 08.00 .04 / B.I. Лемішковський ; Нац. ун-т «Львів. політехніка». - Львів, 2018. - 252 с.

14. Лецер Ю.О. Формування комплексної економіко-організаційної моделі підприємств з розробки інформаційних технологій : дис. ... канд. екон. наук : 08.00.04 / Ю.О. Лецер ; Нац. ун-т водн. госп-ва та природокор. - Рівне, 2018. - 222 с.

15. Малахівська Г.В. Управління лояльністю клієнтів авіакомпаній на засадах соціально-відповідального маркетингу : дис. ... канд. екон. наук : 08.00.04 / Г.В. Малахівська ; Нац. авіац. ун-т. - Київ, 2019. - 307 с.

16. Мельник T.M. Обліково-аналітичне забезпечення управління інвестиційними проектами на підприємствах роздрібної торгівлі : дис. ... канд. екон. наук : 08.00.09 / Т.М. Мельник ; Львів. комерц. академія. - Львів, 2015. - $301 \mathrm{c}$.

17. Мінєнкова О.В. Моделювання оцінки діяльності підприємства на основі збалансованої системи показників : дис. ... канд. екон. наук : 08.00.11 / О.В. Мінєнкова ; Харк. нац. екон. ун-т ім. С.Кузнеця. - Харків, 2018. - 293 с.

18. Науменко I.B. Моделі та інформаційні технології управління підприємствами залізничного транспорту на основі збалансованої системи показників : дис. ... канд. екон. наук : 08.00 .11 / I.B Науменко ; Київ. нац. екон. ун-т ім. В.Гетьмана. - Київ, 2015. - 215 с.

19. Островська Г.Й. Управління вартістю вертикально-інтегрованих підприємств нафтогазової промисловості : дис. ... канд. екон. наук : 08.00.04 / Г.Й. Островська ; Терн. нац. екон. ун-т. - Тернопіль, 2007. - 254 с.

20. Підлипна Р.П. Аналіз стратегій діяльності торговельних підприємств : дис. ... канд. екон. наук : 08.00 .09 / Р.П. Підлипна ; Львів. комерц. академія. - Львів, 2009. - 203 с.

21. Побережний Р.О. Формування стратегії розвитку машинобудівного підприємства на основі збалансованої системи показників : дис. ... канд. екон. наук : 08.00 .04 / Р.О. Побережний ; Нац. техн. ун-т «Харків. політехн. ін-т». - Харків, 2015. - 364 с.

22. Полішук С.В. Формування інтегрованої системи бюджетування на підприємствах машинобудування : дис. ... канд. екон. наук : 08.00.04 / С.В. Поліщук ; НТУУ «Київ. політехн. інст-т». - К., 2014. - 221 с.

23. Пономарьова I.B. Формування стратегії розвитку підприємства на основі збалансованої системи показників : дис. ... канд. екон. наук : 08.00 .04 / I.В. Пономарьова ; Східноукр. нац. ун-т ім. В.Даля. Луганськ, 2011. - 206 с.

24. Сапачова М.С. Формування і розвиток кооперованих зв'язків підприємств спиртової промисловості : дис. ... канд. екон. наук : 08.00.04 / М.С. Сапачова ; Терн. нац. екон. ун-т. - Тернопіль, 2009. - 215 с.

25. Соловій Х.Я. Формування та використання збалансованих систем показників інноваційної діяльності підприємств : автореф. дис. на здобуття наук. ступеня канд. екон. наук : 08.00 .04 / X.Я. Соловій ; Нац. ун-т «Львів. політехніка». - Львів, 2013. - 27 с.

26. Трут O.O. Управління результативністю організації: теоретико-методологічні та прикладні засади : дис. ... д-ра екон. наук : 08.00 .04 / О.О. Трут ; Львів. торг.-екон. ун-т. - Львів, 2019. - 527 с.

27. Фаізова С.О. Стратегічне управління металургійним підприємством на основі збалансованого підходу : дис. ... канд. екон. наук : 08.00.04 / С.О. Фаізова ; Нац. металур. академія. - Дніпропетровськ, 2015. - 257 с.

28. Шайкан A.B. Бухгалтерський облік в аспекті стратегічного управління промисловим підприємством : дис. ... д-ра екон. наук : 08.00.09 / А.В. Шайкан; Київ. нац. екон. ун-т ім. В.Гетьмана. - Київ, 2009. - 303 с.

29. Швари I.B. Механізм забезпечення ефективності антикризового управління підприємством (на прикладі машинобудівних підприємств) : дис. ... канд. екон. наук : 08.00.04 / I.B. Швари ; Він. нац. техн. ун-т. Вінниця, 2007. -229 с.

30. Штереверя А.В. Формування збалансованої системи показників оцінки діяльності підприємства : дис. ... канд. екон. наук : 08.00.04 / А.В. Штереверя ; Хар. нац. екон. ун-т. - Харків, 2010. - 248 с.

31. Яәнюк I.M. Стратегія управління діяльністю підприємств на основі збалансованої системи показників : дис. ... канд. екон. наук : 08.00 .04 / I.M. Ягнюк ; ПВНЗ «Макіївський екон.-гуман. інститут». - Макіївка, 2010. $-236 \mathrm{c}$

32. Яремко І.Й. Оцінювання та формування вартості машинобудівних підприємств : дис. ... д-ра екон. наук : 08.00 .04 / I.Й. Яремко ; Нац. ун-т «Львів. політехніка». - Львів, 2010. - 490 с.

33. Ярошенко I.B. Збалансована система показників як інструмент управління інтегрованими структурами бізнесу : дис. ... канд. екон. наук : 08.00.04 / І.В. Ярошенко ; Наук.-досл. центр індустр. проблем розв. НАН України. - Харків, 2008. - 322 с. 


\section{References:}

1. Andrijenko, N.M. (2015), «Organizacijno-ekonomichne zabezpechennja efektyvnogo upravlinnja komercijnoju dijal'nistju promyslovogo pidpryjemstva», Ph.D. Thesis of dissertation, 08.00.04, Institute of Market Problems and Economic-Ecological Research, Odessa, Ukraine, 213 p.

2. Achkasova, O.V. (2011), «Udoskonalennja vyznachennja strategii' pidpryjemstva v umovah kryzy na osnovi zbalansovanoi' systemy pokaznykiv», Abstract of Ph.D. dissertation, 08.00.04, Kharkiv National University of Economics, Kharkiv, Ukraine, 24 p.

3. Vysochyna, M.V. (2007), «Funkcional'no-orijentovanyj pidhid do ocinjuvannja efektyvnosti upravlinnja dijal'nistju mashynobudivnogo pidpryjemstva», Ph.D. Thesis of dissertation, 08.00.04, National Academy of Environmental and Resort Construction, Simferopol, Ukraine, $280 \mathrm{p}$.

4. Vostrjakova, V.I. (2017), «Udoskonalennja logistychnoi' systemy rozpodilu produkcii' sil's'kogospodars'kyh pidpryjemstv», Ph.D. Thesis of dissertation, 08.00.04, Vinnytsia National Agrarian University, Vinnytsia, Ukraine, $233 \mathrm{p}$.

5. Golovaj, N.M. (2009), «Oblik ta analiz v upravlinni intelektual'nym kapitalom pidpryjemstva», Ph.D. Thesis of dissertation, 08.00.09, Kyiv National University of Trade And Economics, Kyiv, Ukraine, 204 p.

6. Zhygulin, O.A. (2019), «Naprjamy udoskonalennja upravlinnja konkurentospromozhnistju pidpryjemnyc'kyh struktur agrobiznesu Ukrai'ny», D.Sc. Thesis of dissertation, 08.00.04, National University of Life and Environmental Sciences of Ukraine, Kyiv, Ukraine, 480 p.

7. Ivannikova, M.M. (2016), «Marketyng u formuvanni konkurentnyh perevag pidpryjemstva», Ph.D. Thesis of dissertation, 08.00.04, Kyiv National Economical University named after Vadym Hetman, Kyiv, Ukraine, 276 p.

8. Ivanchenko, N.O. (2007), «Mehanizm upravlinnja nematerial'nymy aktyvamy na pidpryjemstvah legkoi' promyslovosti», Ph.D. Thesis of dissertation, 08.00.04, Kyiv National University of Technologies and Design, Kyiv, Ukraine, 187 p.

9. Kadnychans'kyj, M.V. (2009), «Organizacijno-ekonomichnyj mehanizm korporatyvnogo upravlinnja budivel'nyh holdyngovyh kompanij za zbalansovanoju systemoju pokaznykiv», Ph.D. Thesis of dissertation, 08.00.04, National University of Urban Economy in Kharkiv, Kharkiv, Ukraine, 151 p.

10. Kaplan, R.S. and Norton, D.P. (2003), Sbalansirovannaya sistema pokazatelei. Ot strategii k deistviyu, Moskva, ZAO «Olymp-Byznes», $304 \mathrm{p}$.

11. Kargin, B.B. (2019), «Vprovadzhennja innovacijnyh informacijnyh tehnologij u dijal'nist' promyslovyh pidpryjemstv», Ph.D. Thesis of dissertation, 08.00.04, Pryazovskyi State Technical University, Mariupol, Ukraine, $242 \mathrm{p}$.

12. Kurnosova, O.A. (2010), «Upravlenie razvitiem predpriyatii na osnove protsessnykh innovatsii», Ph.D. Thesis of dissertation, 08.00.04, Donetsk National University, Donetsk, Ukraine, 293 p

13. Lemishkovs'kyj, V.I. (2018), «Rozvytok kontrolingovoi' dijal'nosti mashynobudivnyh pidpryjemstv», Ph.D. Thesis of dissertation, 08.00.04, Lviv Polytechnic National University, Lviv, Ukraine, 252 p.

14. Lecer, Yu.O. (2018), «Formuvannja kompleksnoi' ekonomiko-organizacijnoi' modeli pidpryjemstv z rozrobky informacijnyh tehnologij», Ph.D. Thesis of dissertation, 08.00.04, National University of Water and Environmental Engineering, Rivne, Ukraine, 222 p.

15. Malahivs'ka, H.V. (2019), «Upravlinnja lojal'nistju klijentiv aviakompanij na zasadah social'no-vidpovidal'nogo marketyngu», Ph.D. Thesis of dissertation, 08.00.04, National Aviation University, Kyiv, Ukraine, 307 p.

16. Mel'nyk, T.M. (2015), «Oblikovo-analitychne zabezpechennja upravlinnja investycijnymy proektamy na pidpryjemstvah rozdribnoi' torgivli», Ph.D. Thesis of dissertation, 08.00.09, Lviv Academy of Commerce, Lviv, Ukraine, $301 \mathrm{p}$.

17. Minjenkova, O.V. (2018), «Modeljuvannja ocinky dijal'nosti pidpryjemstva na osnovi zbalansovanoi' systemy pokaznykiv», Ph.D. Thesis of dissertation, 08.00.11, Simon Kuznets Kharkiv National University of Economics, Kharkiv, Ukraine, 293 p.

18. Naumenko, I.V. (2015), «Modeli ta informacijni tehnologii' upravlinnja pidpryjemstvamy zaliznychnogo transportu na osnovi zbalansovanoi' systemy pokaznykiv», Ph.D. Thesis of dissertation, 08.00.11, Kyiv National Economical University named after Vadym Hetman, Kyiv, Ukraine, 215 p.

19. Ostrovs'ka, H.I. (2007), «Upravlinnja vartistju vertykal'no-integrovanyh pidpryjemstv naftogazovoi' promyslovosti», Ph.D. Thesis of dissertation, 08.00.04, Ternopil National Economical University, Ternopil, Ukraine, $254 \mathrm{p}$.

20. Pidlypna, R.P. (2009), «Analiz strategij dijal'nosti torgovel'nyh pidpryjemstv», Ph.D. Thesis of dissertation, 08.00.09, Lviv Academy of Commerce, Lviv, Ukraine, 203 p.

21. Poberezhnyj, R.O. (2015), «Formuvannja strategii' rozvytku mashynobudivnogo pidpryjemstva na osnovi zbalansovanoi' systemy pokaznykiv», Ph.D. Thesis of dissertation, 08.00.04, National Technical University «Kharkiv Polytechnic Institute», Kharkiv, Ukraine, 364 p.

22. Polishhuk, S.V. (2014), «Formuvannja integrovanoi' systemy bjudzhetuvannja na pidpryjemstvah mashynobuduvannja», Ph.D. Thesis of dissertation, 08.00.04, National Technical University of Ukraine «Igor Sikorsky Kyiv Polytechnic Institute», Kyiv, Ukraine, 221 p.

23. Ponomar'ova, I.V (2011), «Formuvannja strategii' rozvytku pidpryjemstva na osnovi zbalansovanoi' systemy pokaznykiv», Ph.D. Thesis of dissertation, 08.00.04, Volodymyr Dahl East Ukrainian National University, Lugans'k, Ukraine, 206 p.

24. Sapachova, M.S. (2009), «Formuvannja i rozvytok kooperovanyh zv'jazkiv pidpryjemstv spyrtovoi' promyslovosti», Ph.D. Thesis of dissertation, 08.00.04, Ternopil National Economical University, Ternopil, Ukraine, $215 \mathrm{p}$. 
25. Solovij, Kh.Ia. (2013), «Formuvannja ta vykorystannja zbalansovanyh system pokaznykiv innovacijnoi' dijal'nosti pidpryjemstv», Abstract of Ph.D. dissertation, 08.00.04, L'viv Polytechnic National University, L'viv, Ukraine, 27 p.

26. Trut, O.O. (2019), «Upravlinnja rezul'tatyvnistju organizacii': teoretyko-metodologichni ta prykladni zasady», D.Sc. Thesis of dissertation, 08.00.04, L'viv University of Trades and Economics, L'viv, Ukraine, 527 p.

27. Faizova, S.O. (2015), «Strategichne upravlinnja metalurgijnym pidpryjemstvom na osnovi zbalansovanogo pidhodu», Ph.D. Thesis of dissertation, 08.00.04, National Metallurgical Academy of Ukraine, Dnipropetrovs'k, Ukraine, $257 \mathrm{p}$.

28. Shajkan, A.V. (2009), «Buhgalters'kyj oblik v aspekti strategichnogo upravlinnja promyslovym pidpryjemstvom», D.Sc. Thesis of dissertation, 08.00.09, Kyiv National Economical University named after Vadym Hetman, Kyiv, Ukraine, 303 p.

29. Shvarc, I.V. (2007), «Mehanizm zabezpechennja efektyvnosti antykryzovogo upravlinnja pidpryjemstvom (na prykladi mashynobudivnyh pidpryjemstv)», Ph.D. Thesis of dissertation, 08.00.04, Vinnytsia National Technical University, Vinnytsia, Ukraine, 229 p.

30. Shtereverja, A.V. (2010), «Formuvannja zbalansovanoi' systemy pokaznykiv ocinky dijal'nosti pidpryjemstva», Ph.D. Thesis of dissertation, 08.00.04, Kharkiv National University of Economics, Kharkiv, Ukraine, 248 p.

31. Jagnjuk, I.M. (2010), «Strategija upravlinnja dijal'nistju pidpryjemstv na osnovi zbalansovanoi' systemy pokaznykiv», Ph.D. Thesis of dissertation, 08.00.04, Makeevka Institute of Economics and Humanities, Makeevka, Ukraine, $236 \mathrm{p}$.

32. Jaremko, I.I. (2010), «Ocinjuvannja ta formuvannja vartosti mashynobudivnyh pidpryjemstv», D.Sc. Thesis of dissertation, 08.00.04, Lviv Polytechnic National University, Lviv, Ukraine, 490 p.

33. Jaroshenko, I.V. (2008), «Zbalansovana systema pokaznykiv jak instrument upravlinnja integrovanymy strukturamy biznesu», Ph.D. Thesis of dissertation, 08.00.04, Scientific-Proslidny Center Of Industrial Problems Of Development of The National Academy of Sciences of Ukraine, Kharkiv, Ukraine, $322 \mathrm{p}$.

Шиманська Катерина Володимирівна - доктор економічних наук, доцент, завідувач кафедри цифрової економіки та міжнародних економічних відносин Державного університету «Житомирська політехніка».

Наукові інтереси:

- проблеми міжнародної торгівлі та міжнародна торговельна політика;

- інтернаціоналізація бізнесу;

- збалансована система показників.

Завалій Тетяна Олександрівна - аспірантка кафедри цифрової економіки та міжнародних економічних відносин Державного університету «Житомирська політехніка».

Наукові інтереси:

- проблематика вартісно орієнтованого управління;

- клієнтський капітал підприємства;

- збалансована система показників. 